Article

\title{
Two Complete Mitogenomes of Chalcididae (Hymenoptera: Chalcidoidea): Genome Description and Phylogenetic Implications
}

\author{
Huifeng Zhao ${ }^{1} \mathbb{D}$, Ye Chen ${ }^{1}$, Zitong Wang ${ }^{2}$, Haifeng Chen ${ }^{1}$ and Yaoguang Qin ${ }^{1, *}$ \\ 1 Hebei Key Laboratory of Animal Diversity, College of Life Science, Langfang Normal University, \\ Langfang 065000, China; zhaohf@lfnu.edu.cn (H.Z.); chenye@lfnu.edu.cn (Y.C.); \\ chenhaifeng@lfnu.edu.cn (H.C.) \\ 2 School of Forestry, Northeast Forestry University, Harbin 150040, China; wangzitong@nefu.edu.cn \\ * Correspondence: qinyaoguang@lfnu.edu.cn
}

check for updates

Citation: Zhao, H.; Chen, Y.; Wang, Z.; Chen, H.; Qin, Y. Two Complete Mitogenomes of Chalcididae (Hymenoptera: Chalcidoidea): Genome Description and Phylogenetic Implications. Insects 2021, 12, 1049. https://doi.org/ $10.3390 /$ insects 12121049

Academic Editors: Brian T. Forschler and Andrew Polaszek

Received: 18 September 2021 Accepted: 22 November 2021 Published: 23 November 2021

Publisher's Note: MDPI stays neutral with regard to jurisdictional claims in published maps and institutional affiliations.

Copyright: (c) 2021 by the authors. Licensee MDPI, Basel, Switzerland. This article is an open access article distributed under the terms and conditions of the Creative Commons Attribution (CC BY) license (https:/ / creativecommons.org/licenses/by/ $4.0 /)$.
Simple Summary: The Chalcididae are a moderate-sized family of the superfamily Chalcidoidea in Hymenoptera, comprising 1548 species in 87 genera worldwide. Some species are potential natural enemies of pests in agriculture and forestry. Currently, there are still some controversies about the monophyly of Chalcididae and the phylogenetic relationships between Chalcididae and other families in Chalcidoidea. Based on the fact that no mitogenomic phylogenetic analyses of all of the published mitogenomes of Chalcidoidea have been conducted and no complete mitogenome of Chalcididae species has been reported, two newly completed mitochondrial genomes of Chalcididae species (Brachymeria lasus and Haltichella nipponensis) were sequenced and analyzed. The results show that the two chalcidid mitogenomes have quite similar structures and features. In phylogenetic analyses based on 13 PCGs of mitogenomes, the basal position and monophyly of Chalcididae within Chalcidoidea were supported by all trees derived from maximum likelihood (ML) and Bayesian inference (BI) methods.

Abstract: The complete mitochondrial genomes of two species of Chalcididae were newly sequenced: Brachymeria lasus and Haltichella nipponensis. Both circular mitogenomes are 15,147 and 15,334 bp in total length, respectively, including 13 protein-coding genes (PCGs), two ribosomal RNA genes (rRNAs), and 22 transfer RNA genes (tRNAs) and an A+T-rich region. The nucleotide composition indicated a strong A/T bias. All PCGs of B. lasus and H. nipponensis began with the start codon ATD, except for B. lasus, which had an abnormal initiation codon TTG in ND1. Most PCGs of the two mitogenomes are terminated by a codon of TAR, and the remaining PCGs by the incomplete stop codon T or TA (ATP6, COX3, and ND4 in both species, with an extra CYTB in B. lasus). Except for trnS1 and trnF, all tRNAs can be folded into a typical clover structure. Both mitogenomes had similar control regions, and two repeat units of $135 \mathrm{bp}$ were found in H. nipponensis. Phylogenetic analyses based on two datasets (PCG123 and PCG12) covering Chalcididae and nine families of Chalcidoidea were conducted using two methods (maximum likelihood and Bayesian inference); all the results support Mymaridae as the sister group of the remaining Chalcidoidea, with Chalcididae as the next successive group. Only analyses of PCG123 generated similar topologies of Mymaridae $+($ Chalcididae $+($ Agaonidae + remaining Chalcidoidea $)$ ) and provided one relative stable clade as Eulophidae + (Torymidae + (Aphelinidae + Trichogrammatidae) $)$. Our mitogenomic phylogenetic results share one important similarity with earlier molecular phylogenetic efforts: strong support for the monophyly of many families, but a largely unresolved or unstable "backbone" of relationships among families.

Keywords: mitogenome; Chalcidoidea; Chalcididae; phylogeny 


\section{Introduction}

The Chalcididae are a moderate-sized family of the superfamily Chalcidoidea in Hymenoptera, with about 87 genera and 1548 species worldwide. This family appears in greatest diversity in the tropics. Members of Chalcididae have a medium to large body size, which varies from 1.5 to $15 \mathrm{~mm}$ in length, and they represent some of the largest specimens in Chalcidoidea [1]. Most species of Chalcididae are solitary primary parasitoids of Lepidoptera, Diptera and Coleoptera, along with a few hyper-parasitizing tachinids or ichneumonids [2], and thus can regulate populations of other insects in the ecosystems naturally.

The monophyly and phylogenetic relationships of Chalcididae in Chalcidoidea have been controversial for a long time. Morphologically, the Chalcididae was treated as a monophyletic group based largely on four putative synapomorphies: labrum exposed and contiguous with anterior clypeal margin, base of mandibles exposed and straight, parascutal and axillar carinae meeting at the transscutal articulation, and genal carina $[3,4]$. However, the genal carina in Eurytomidae and Pteromalidae, and the highly homoplastic nature of the three other features in Chalcidoidea, make the monophyly of Chalcididae seem unreliable [3]. As for the phylogenetic relationships of the Chalcididae, they have often been considered to be closely related to Eurytomidae and Leucospidae in morphological phylogenetics [3].

Molecular efforts, devoted to reconstructing the phylogeny of Chalcidoidea, include analysis of ribosomal markers [5,6], and extensive transcriptomic data [7,8]. In the analysis of ribosomal genes (18S and $28 \mathrm{~S}$ ), five subfamilies of the Chalcididae are not monophyletic [6]. However, the combined morphological and molecular characteristics strongly support the monophyly of the Chalcididae [9]. Additionally, all these results generally suggest that the Chalcididae never cluster with Eurytomidae and Leucospidae $[5,7,8]$.

These conflicting results cause the aforementioned phylogenetic question to remain controversial and indicate the requirement for using various molecular data to understand the systematic position and the monophyly of Chalcididae within Chalcidoidea. Mitogenome data seem a good choice to answer these questions. Mitogenomes of insects are circular DNA molecules that code for 13 proteins, 22 transfer RNA genes, and two ribosomal RNAs [10]. Mitogenome data have been widely used in phylogenetic analysis [11-23]. Until now, however, only one partial mitogenome of the Chalcididae has been submitted to Genbank, which has significantly impeded the unveiling of systematic confusions of Chalcididae.

Here, the two full mitogenomes of B. lasus and H. nipponensis [24,25] were newly sequenced and analyzed, which contributed to better understanding of the characteristics of the mitogenome of the Chalcididae. In addition, phylogenetic analyses including 53 published mitogenomes together with our de novo data, which represented 10 families of Chalcidoidea, were carried out to assess the systematic position and monophyly of Chalcididae, and to deeply understand the phylogeny of Chalcidoidea.

\section{Materials and Methods}

\subsection{Sample Preparation and DNA Extraction}

B. lasus and H. nipponensis were collected in Xishuangbanna, Yunnan Province, China on 29 April $2019\left(21^{\circ} 53^{\prime} 37^{\prime} \mathrm{N}, 101^{\circ} 16^{\prime} 15^{\prime} \mathrm{E}\right)$, and on 11 May $2019\left(21^{\circ} 53^{\prime} 44.76^{\prime} \mathrm{N}, 101^{\circ} 16^{\prime} 39.88^{\prime} \mathrm{E}\right)$, respectively. Total genomic DNA was extracted using a DNeasy Blood \& Tissue kit (QIAGEN, Dusseldorf, Germany), according to the manufacturer's instructions. DNA concentrations were measured using a DeNovix DS-11 Spectrophotometer, and its integrity was examined with agarose gel electrophoresis by $0.5 \times$ TBE (Tris base, Boric acid and EDTA) buffer with 4 volts/centimeter for $45 \mathrm{~min}$.

\subsection{High throughout Sequencing}

The genomic DNA of two chalcidids was qualified for next generation sequencing and was fragmented to 350 bp by a Covaris S220 Focused Ultrasonicator (Covaris, MA, USA). The sequence libraries were constructed using TruSeq DNA LT Sample Preparation Kit 
(Illumina, Inc., San Diego, CA, USA). After repairing the blunt ends, adenylating $3^{\prime}$ ends and ligating adapters, the fragmented DNA was enriched. Then, both libraries were pooled and sequenced using an Illumina Hiseq X10 platform. The obtained raw reads were filtered by removing adaptor sequences, contamination, and low-quality reads.

\subsection{Data Assemble and Annotation}

The clean data were assembled with MitoZ v2.4 [26]. The assembled circular mitogenomes were reordered COX1 as a start gene with the script 'Mitogenome_reorder.py' [26]. The annotation of the two mitochondrial genomes was performed using MitoZ and the MITOS2 online server (http:/ / mitos2.bioinf.uni-leipzig.de/index.py, (accessed on 30 June 2021)), and the secondary structures of tRNAs were plotted by the MITOS2 web server. Furthermore, both mitogenomes were corrected manually.

\subsection{Statistics of the Chalcididae Mitochondrial Genomes}

The nucleotide composition of the whole mitogenome, PCGs, 22 tRNAs, and 2 rRNAs and the relative synonymous codon usage (RSCU) of the PCGs of both chalcidid mitogenomes were calculated in MEGA 5 [27]. Nucleotide compositional skew was calculated according to the following formula: AT skew $=[A-T] /[A+T], G C$ skew $=[G-C] /[G+C])[28]$.

\subsection{Phylogenetic Analysis}

To investigate the phylogeny of Chalcididae in Chalcidoidea, we reconstructed the family-level relationships within Chalcidoidea using two datasets of the 13 PCGs with two inference methods (BI and ML). The mitogenomic phylogeny of Chalcidoidea was reconstructed with 53 ingroups ( 51 online data and 2 newly produced data in this study), representing 10 families, and 3 species close to Chalcidoidea were chosen as outgroups. The details of taxa are shown in Table 1.

Table 1. Mitogenomes of Chalcidoidea and outgroups used in this study.

\begin{tabular}{cccc}
\hline Family & Taxa & GenBank Accession No. & References \\
\hline Agaonidae & Ceratosolen solmsi & JF816396 & {$[29]$} \\
& Ceratosolen fusciceps & MT916179 & {$[30]$} \\
Agaonidae & Dolichoris vasculosae & MT947596 & {$[31]$} \\
& Eupristina koningsbergeri & MT947597 & {$[30]$} \\
& Kradibia gibbosae & MT947598 & {$[30]$} \\
& Wiebesia pumilae & MT947601 & {$[30]$} \\
Aphelinidae & Platyscapa corneri & MT947604 & {$[30]$} \\
& Encarsia formosa & MG813797 & {$[32]$} \\
Chalcididae & Encarsia obtusiclava & MG813798 & {$[32]$} \\
& Brachymeria sp. & MG923487 & {$[18]$} \\
Encyrtidae & Brachymeria lasus & MZ615567 & This study \\
& Haltichella nipponensis & MZ615568 & This study \\
& Encyrtus infelix & MH574908 & {$[33]$} \\
Encyrtus infelix & MH729198 & {$[33]$} \\
& Encyrtus sasakii & MK111647 & unpublished \\
& Encyrtus sasakii & MK111648 & unpublished \\
& Encyrtus sasakii & MK189126 & unpublished \\
& Encyrtus sasakii & MK189127 & unpublished \\
\hline
\end{tabular}


Table 1. Cont.

\begin{tabular}{|c|c|c|c|}
\hline Family & Taxa & GenBank Accession No. & References \\
\hline & Encyrtus eulecaniumiae & MK189128 & unpublished \\
\hline & Encyrtus eulecaniumiae & MK189129 & unpublished \\
\hline & Encyrtus eulecaniumiae & MK189130 & unpublished \\
\hline & Encyrtus eulecaniumiae & MK189131 & unpublished \\
\hline & Encyrtus rhodococcusiae & MK189132 & unpublished \\
\hline & Encyrtus rhodococcusiae & MK189133 & unpublished \\
\hline & Encyrtus rhodococcusiae & MK189134 & unpublished \\
\hline & Encyrtus rhodococcusiae & MK189135 & unpublished \\
\hline & Aenasius arizonensis & MK630013 & [34] \\
\hline & Diaphorencyrtus aligarhensis & MN274569 & [35] \\
\hline & Platencyrtus parkeri & MN296710 & unpublished \\
\hline & Metaphycus eriococci & MW255970 & unpublished \\
\hline \multirow[t]{3}{*}{ Eulophidae } & Tamarixia radiata & MN123622 & [31] \\
\hline & Necremnus tutae & MT916846 & {$[36]$} \\
\hline & Chouioia cunea & MW192646 & [37] \\
\hline \multirow[t]{3}{*}{ Eurytomidae } & Eurytoma sp. & KX066374 & {$[38]$} \\
\hline & Eurytoma sp. & MG923494 & [18] \\
\hline & Sycophila sp. & MT947603 & {$[30]$} \\
\hline Mymaridae & Gonatocerus sp. & MF776883 & [39] \\
\hline \multirow[t]{3}{*}{ Pteromalidae } & Philotrypesis sp. & JF808722 & {$[40]$} \\
\hline & Philotrypesis pilosa & JF808723 & [40] \\
\hline & Pteromalus puparum & MG923513 & [18] \\
\hline \multirow[t]{5}{*}{ Pteromalidae } & Pteromalus puparum & MH051556 & [41] \\
\hline & Pachyneuron aphidis & MK577639 & [42] \\
\hline & Apocrypta bakeri & MT906648 & {$[30]$} \\
\hline & Philotrypesis tridentata & МT947602 & {$[30]$} \\
\hline & Anisopteromalus calandrae & MW817149 & [43] \\
\hline \multirow[t]{2}{*}{ Torymidae } & Podagrion sp. & MF795597 & {$[44]$} \\
\hline & Torymus sp. & MG923516 & [18] \\
\hline \multirow[t]{6}{*}{ Trichogrammatidae } & Megaphragma amalphitanum & KT373787 & [1] \\
\hline & Trichogramma japonicum & KU577436 & [45] \\
\hline & Trichogramma ostriniae & KU577437 & [45] \\
\hline & Trichogramma dendrolimi & KU836507 & unpublished \\
\hline & Trichogramma chilonis & MT712144 & unpublished \\
\hline & Trichogramma chilonis & MW789210 & unpublished \\
\hline Cynipoidea & Trichagalma acutissimae & MN928529 & [46] \\
\hline Platygastroidea & Telenomus remus & MT906647 & [47] \\
\hline Proctotrupoidea & Trichopria drosophilae & MN966974 & [48] \\
\hline
\end{tabular}

The two datasets were PCG123 (13 PCGs including all codon positions) and PCG12 (13 PCGs without third codon positions). Bayesian inference (BI) and maximum likelihood (ML) methods were used to reconstruct phylogenetic trees.

For PCG123 and PCG12 datasets, the best DNA model based on the Akaike information criterion (AIC) was obtained using jModeltest 2.1.7 [49] (Table S1), and those selected models were used by BI with the software MrBayes 3.2.6. To ensure that the average standard deviation of split frequencies was less than 0.01 , eight million generations were run with sampling every 1000 generations. Node support was assessed by posterior probabilities (PPs). The ML analyses were performed using RAxML 8.2.4 [50] under the GTRCAT model, and branch support for the resulting phylogenies was evaluated using 1000 bootstrap replicates (BS) with a partitioned strategy, and other settings were default.

Tracer v1.6 [51] was used to check the likelihoods of all parameters of BI analyses of the two datasets to ensure the effective sample size (ESS) values greater than 200 . The consensus tree was calculated by discarding the first $25 \%$ trees. To verify the consistencies 
of the topologies, both BI and ML analyses were repeated two times, and the phylogenetic trees were visualized by Figtree v.1.4.3 [52].

\section{Results and Discussion}

\subsection{Mitogenome Organization and Base Composition}

The total lengths of mitogenomes in B. lasus and H. nipponensis are 15,147 bp and $15,334 \mathrm{bp}$, respectively. The both complete mitogenomes were investigated here, and were found to be composed of circular double-stranded molecules. Each mitogenome contains the typical set of 37 genes, including 13 PCGs, 22 tRNAs, 2 rRNAs and an A + T-rich area. The majority strand (J-strand) encodes 27 genes (11 PCGs, 14 tRNAs and 2 rRNAs), while the remaining 10 genes are located on the minority strand (N-strand) (two PCGs and eight tRNAs) (Figure 1, Table 2). The circular maps of the two mitogenomes are shown in Figure 1, and the details of annotations for the two complete mitogenomes are shown in Table 2.
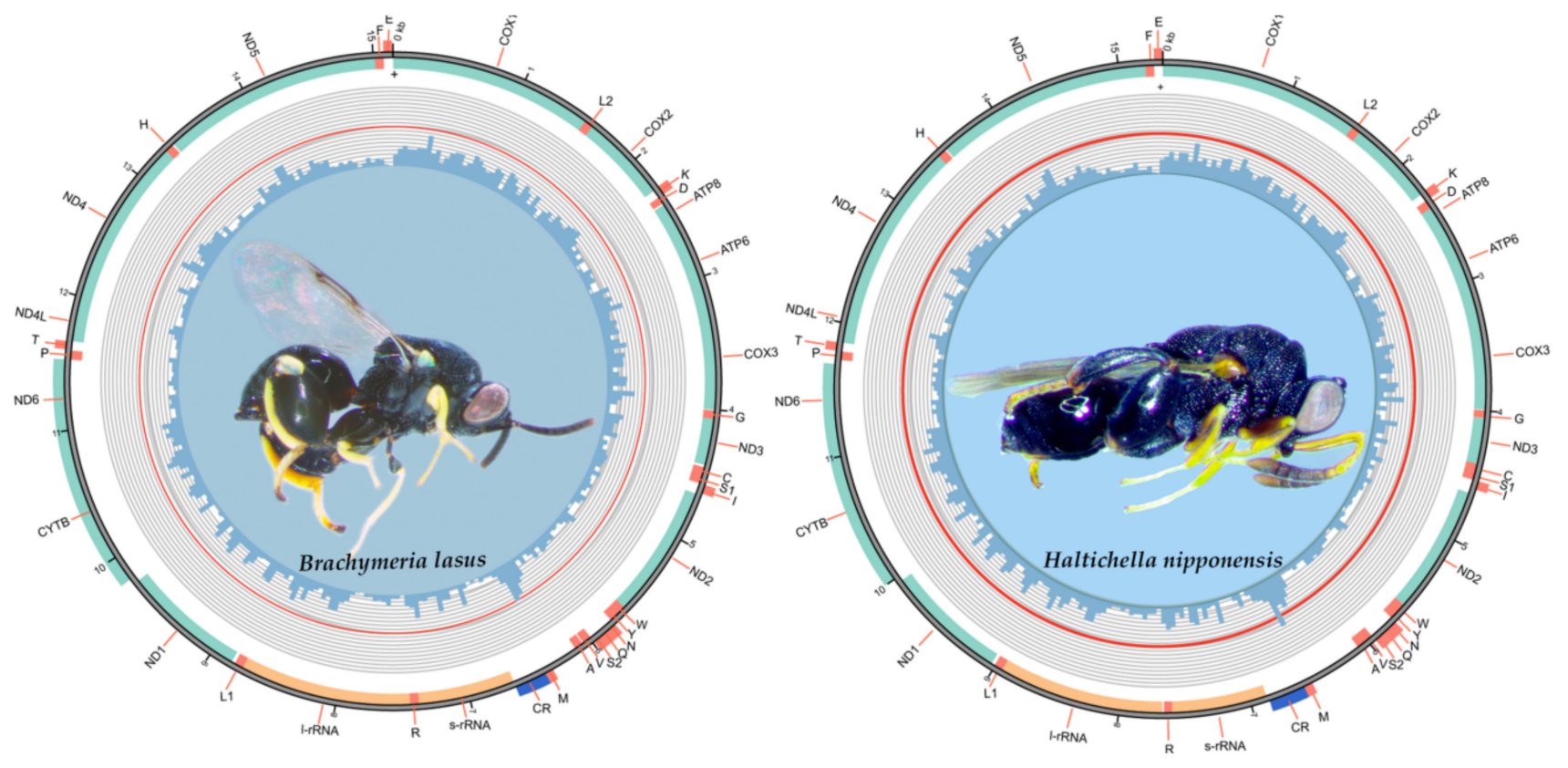

Figure 1. Complete mitochondrial genomes of B. lasus and H. nipponensis. The inner circle indicates the GC content in every 50-site window, and the outer circle shows the arrangement of the genes: light green for the PCGs, salmon for tRNAs, orange for rRNAs, and blue for control region.

In comparison to this newly sequenced complete mitogenome of $B$. lasus, the previous partial mitogenome of Brachymeria sp. is 15,092 bp in length [18], which contains two trnMs and lacks trnA and s-rRNA. The mitogenome map of Brachymeria sp. is shown in Figure S1. Another differentiation is the position of trnR. In B. latus, trnR is located between s-rRNA and 1-rRNA while between trnQ and trnS2 in Brachymeria sp. Given no change of gene order between B. lasus and H. nipponensis, this result only suggests the existence of gene rearrangement in the genus Brachymeria.

Nucleotide composition for the two newly generated mitogenomes is shown in Supplementary Table S2. The entire sequence indicates a strong A and T bias: $84.5 \%$ for B. lasus and $83.9 \%$ for H. nipponensis. Excluding the A + T-rich regions, the highest AT content was found in the tRNA region, and the lowest was observed in the PCG region. Both of the whole mitogenomes show slightly negative AT-skews $(-0.07$ in B. lasus and -0.08 in H. nipponensis) and positive GC-skews (0.17 in B. lasus and 0.19 in H. nipponensis). 
Table 2. Features of the mitogenomes of B. lasus (left) and H. nipponensis (right).

\begin{tabular}{|c|c|c|c|c|c|c|c|c|}
\hline Feature & Strand & $\begin{array}{l}\text { Position } \\
\text { (from) }\end{array}$ & Position (to) & Length & $\begin{array}{c}\text { Intergenic } \\
\text { Nucleotides }\end{array}$ & Anticodon & $\begin{array}{l}\text { Initial } \\
\text { Codon }\end{array}$ & $\begin{array}{l}\text { Stop } \\
\text { Codon }\end{array}$ \\
\hline COX1 & $\mathrm{J}$ & $1 / 1$ & $1542 / 1536$ & $1542 / 1536$ & $-5 /-5$ & & ATG/ATA & TAA \\
\hline $\operatorname{trnL2}$ & $\mathrm{J}$ & $1538 / 1532$ & $1603 / 1597$ & $66 / 66$ & $0 / 0$ & TAA & & \\
\hline COX2 & $\mathrm{J}$ & $1604 / 1598$ & $2269 / 2260$ & $666 / 663$ & $-8 /-8$ & & ATT & TAA \\
\hline $\operatorname{trnK}$ & $\mathrm{N}$ & $2262 / 2253$ & $2331 / 2322$ & $70 / 70$ & $-1 /-1$ & TTT & & \\
\hline $\operatorname{trn} D$ & $\mathrm{~J}$ & $2331 / 2322$ & $2383 / 2385$ & $53 / 64$ & $13 / 0$ & GTC & & \\
\hline ATP8 & $\mathrm{J}$ & $2397 / 2386$ & $2552 / 2541$ & $156 / 155$ & $-7 /-7$ & & ATT & TAA \\
\hline ATP6 & $\mathrm{J}$ & $2546 / 2535$ & $3218 / 3207$ & $673 / 673$ & $0 / 0$ & & ATG & $\mathrm{T}$ \\
\hline COX3 & $\mathrm{J}$ & $3219 / 3208$ & $3999 / 3988$ & $781 / 781$ & $6 / 6$ & & ATG & $\mathrm{T}$ \\
\hline $\operatorname{trnG}$ & $\mathrm{J}$ & $4006 / 3995$ & $4070 / 4059$ & $65 / 65$ & $-3 /-4$ & TCC & & \\
\hline ND3 & $\mathrm{J}$ & $4068 / 4056$ & $4418 / 4406$ & $351 / 351$ & $18 /-2$ & & ATA & TAA \\
\hline $\operatorname{trnC}$ & $\mathrm{J}$ & $4437 / 4405$ & $4501 / 4467$ & $65 / 63$ & $0 / 0$ & GCA & & \\
\hline $\operatorname{trnS1}$ & $\mathrm{J}$ & $4502 / 4468$ & $4560 / 4526$ & $59 / 59$ & $-1 / 0$ & TCT & & \\
\hline $\operatorname{trnI}$ & $\mathrm{N}$ & $4560 / 4527$ & $4626 / 4592$ & $67 / 66$ & $16 / 38$ & GAT & & \\
\hline ND2 & $\mathrm{J}$ & $4643 / 4631$ & $5653 / 5617$ & $1011 / 987$ & $-2 /-1$ & & ATA/ATT & TAA \\
\hline $\operatorname{trnW}$ & $\mathrm{J}$ & $5652 / 5617$ & $5720 / 5680$ & $69 / 64$ & $1 / 1$ & TCA & & \\
\hline $\operatorname{trn} Y$ & $\mathrm{~J}$ & $5722 / 5682$ & $5787 / 5749$ & $66 / 68$ & $1 / 1$ & GTA & & \\
\hline $\operatorname{trn} N$ & $\mathrm{~N}$ & $5789 / 5751$ & $5854 / 5815$ & $66 / 65$ & $-1 /-1$ & GTT & & \\
\hline $\operatorname{trn} Q$ & $\mathrm{~N}$ & $5854 / 5815$ & $5921 / 5881$ & $68 / 67$ & $0 / 2$ & TTG & & \\
\hline $\operatorname{trnS2}$ & $\mathrm{N}$ & $5922 / 5884$ & $5986 / 5949$ & $65 / 66$ & $2 / 2$ & TGA & & \\
\hline $\operatorname{trn} V$ & $\mathrm{~J}$ & $5989 / 5952$ & $6054 / 6016$ & $66 / 65$ & $10 / 0$ & TAC & & \\
\hline $\operatorname{trn} A$ & $\mathrm{~J}$ & $6065 / 6017$ & $6128 / 6084$ & $64 / 68$ & $222 / 433$ & TGC & & \\
\hline $\operatorname{trnM}$ & $\mathrm{N}$ & $6351 / 6518$ & $6416 / 6583$ & $66 / 66$ & $0 / 0$ & CAT & & \\
\hline$C R$ & $\mathrm{~J}$ & $6417 / 6584$ & $6652 / 6872$ & $236 / 289$ & $0 / 0$ & & & \\
\hline$s-r R N A$ & $\mathrm{~J}$ & $6653 / 6873$ & $7383 / 7600$ & $731 / 728$ & $-3 /-4$ & & & \\
\hline trnR & $\mathrm{J}$ & $7381 / 7597$ & $7446 / 7658$ & $66 / 62$ & 0/12 & TCG & & \\
\hline$l-r R N A$ & $\mathrm{~J}$ & $7447 / 7671$ & $8740 / 8935$ & $1264 / 1265$ & $0 / 2$ & & & \\
\hline trnL1 & $\mathrm{J}$ & $8741 / 8938$ & $8808 / 9005$ & $68 / 68$ & $27 / 27$ & TAG & & \\
\hline ND1 & $\mathrm{J}$ & $8836 / 9033$ & $9762 / 9959$ & $927 / 927$ & $44 / 42$ & & TTG/ATT & TAA \\
\hline СУТВ & $\mathrm{N}$ & $9807 / 10,002$ & $10,959 / 11,156$ & $1153 / 1155$ & $-20 /-20$ & & ATG & $\mathrm{T} / \mathrm{TAA}$ \\
\hline ND6 & $\mathrm{N}$ & $10,940 / 11,137$ & $11,521 / 11,688$ & $582 / 552$ & $1 / 31$ & & ATT/ATG & TAA \\
\hline $\operatorname{trn} P$ & $\mathrm{~J}$ & $11,523 / 11,720$ & $11,590 / 11,784$ & $68 / 65$ & $6 / 3$ & TGG & & \\
\hline $\operatorname{trnT}$ & $\mathrm{N}$ & $11,597 / 11,788$ & $11,656 / 11,850$ & $60 / 63$ & $4 / 1$ & TGT & & \\
\hline$N D 4 L$ & $\mathrm{~J}$ & $11,661 / 11,853$ & $11,945 / 12,137$ & $285 / 285$ & $-7 /-7$ & & ATT & TAA \\
\hline ND4 & $\mathrm{J}$ & $11,939 / 12,131$ & $13,272 / 13,464$ & $1334 / 1334$ & $-1 /-1$ & & ATG & $\mathrm{TA}$ \\
\hline $\operatorname{trnH}$ & $\mathrm{J}$ & $13,272 / 13,464$ & $13,333 / 13,528$ & $62 / 65$ & $13 / 12$ & GTG & & \\
\hline ND5 & $\mathrm{J}$ & $13,347 / 13,541$ & $15,014 / 15,205$ & $1668 / 1665$ & $0 /-1$ & & ATT & TAA \\
\hline $\operatorname{trnF}$ & $\mathrm{J}$ & $15,015 / 15,205$ & $15,078 / 15,269$ & $64 / 65$ & $-2 / 0$ & GAA & & \\
\hline $\operatorname{trn} E$ & $\mathrm{~N}$ & $15,077 / 15,270$ & $15,141 / 15,334$ & $65 / 65$ & & TTC & & \\
\hline
\end{tabular}

\subsection{Protein-Coding Genes and Codon Usage}

The total lengths of the 13 PCGs are 11,115 bp in B. lasus and 11,068 bp in H. nipponensis. The lengths of each PCG ranges from $156 \mathrm{bp}$ (ATP8) to $1668 \mathrm{bp}$ (ND5) in B. lasus and from $153 \mathrm{bp}$ (ATP8) to $1665 \mathrm{bp}$ (ND5) in H. nipponensis.

The two mitogenomes of Chalcididae exhibited similar start and stop codons (Table 2). All the initiation codons of PCGs were ATD (ATA, ATG and ATT), except for ND1, which started with TTG in B. lasus, and ATT and ATG were the most frequently used. Three stop codons existed on the two new mitogenomic sequences: TAA, TA and a single T, and TAA was the most frequently used. Truncated termination codons are commonly used in metazoan mitogenomes, which could be completed by the post-transcriptional poly-adenylation [53]. The RSCU values of the two chalcids are shown in Figure 2. The codon UUA (Leu2) was the most commonly used in both mitogenomes. 

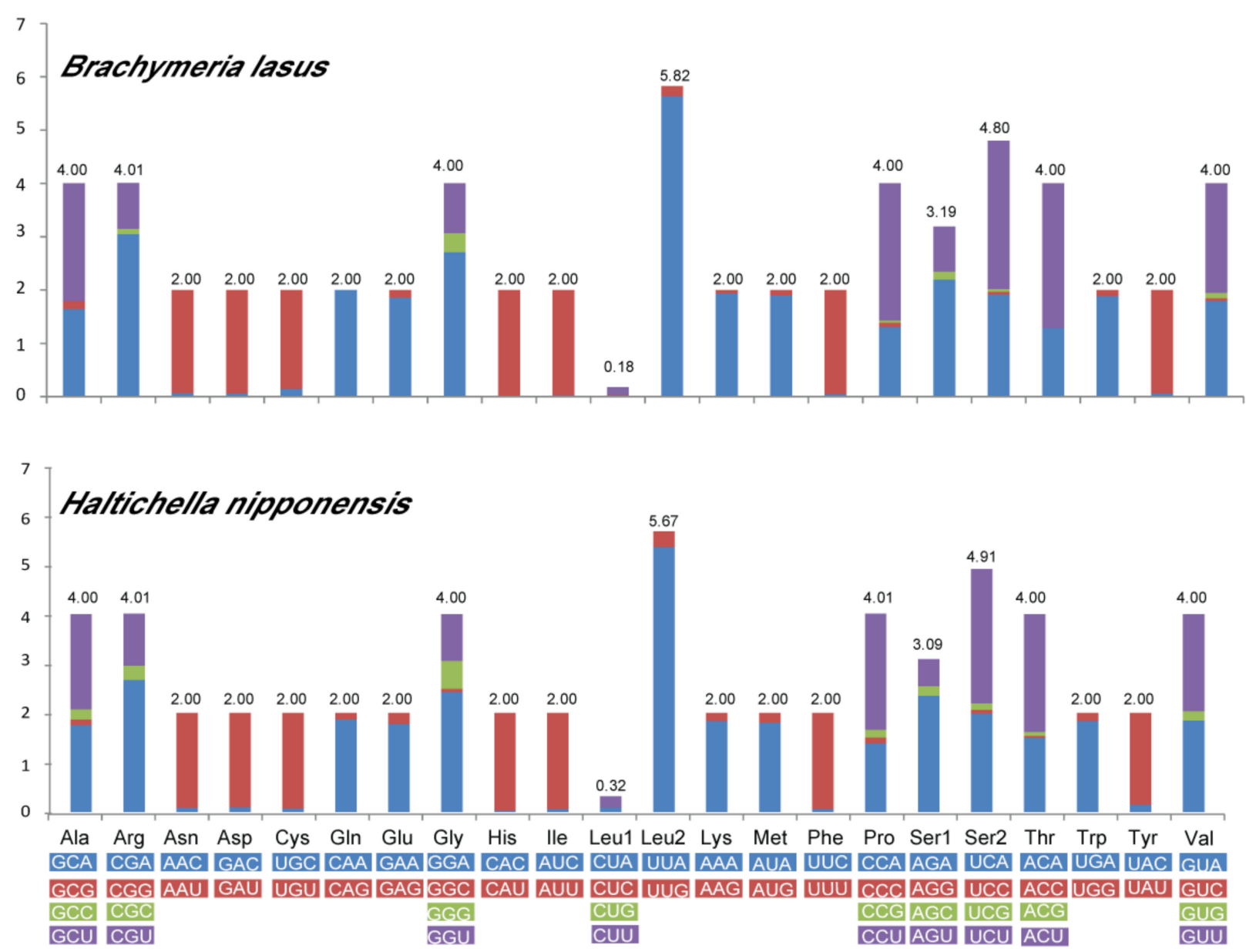

Figure 2. Relative synonymous codon usage (RSCU) in the PCGs of the new sequenced chalcidid mitogenomes. Codon families are indicated below the $X$ axis.

\subsection{Transfer and Ribosomal RNA Genes}

The secondary structures of the 22 tRNAs of the two Chalcididae species are shown in Figure 3. Both species possess the same entire length of tRNAs (1428 bp). The length of the 22 tRNAs ranged from 53 to $70 \mathrm{bp}$ (Table 2). Most of the tRNAs could be folded into a typical clover-leaf structure, except for trnS1, which lost a dihydrouridine (DHU) arm, and trnF, which lost a $\mathrm{T} \psi \mathrm{C}$ loop in the two species; furthermore, trnD lost a $\mathrm{T} \psi \mathrm{C}$ arm in B. lasus (Figure 3). The secondary structures, comprised of the anticodon loop $(7 \mathrm{nt})$ and anticodon stem (5 bp), are conserved in length, while the length of the acceptor stem (5-7 bp), DHU stem (3-4 bp, except for trnS1), and T $\psi \mathrm{C}$ stem (3-5 bp, except for the $\operatorname{trnD}$ in B. lasus) are variable. Additionally, the identified unmatched base pairs (GT) in different stems of tRNAs are shown in Figure 3, and these mismatched nucleotides might be restored during the post-transcriptional editing processes [54].

As for the rRNAs of the two species, both of l-rRNA (rrnL) and s-rRNA (rrnS) genes are encoded on the J-strand. The rrnL has a length of $1294 \mathrm{bp}$ in B. lasus and $1265 \mathrm{bp}$ in H. nipponensis, while rrnS has lengths of 731 and $728 \mathrm{bp}$. Both rRNAs have a heavy AT nucleotide bias, which reaches $86.7 \%$ and $85.8 \%$, respectively. Similarly, a positive AT-skew and GC-skew are shown in the rRNAs of these two newly sequenced mitochondrial genomes. 

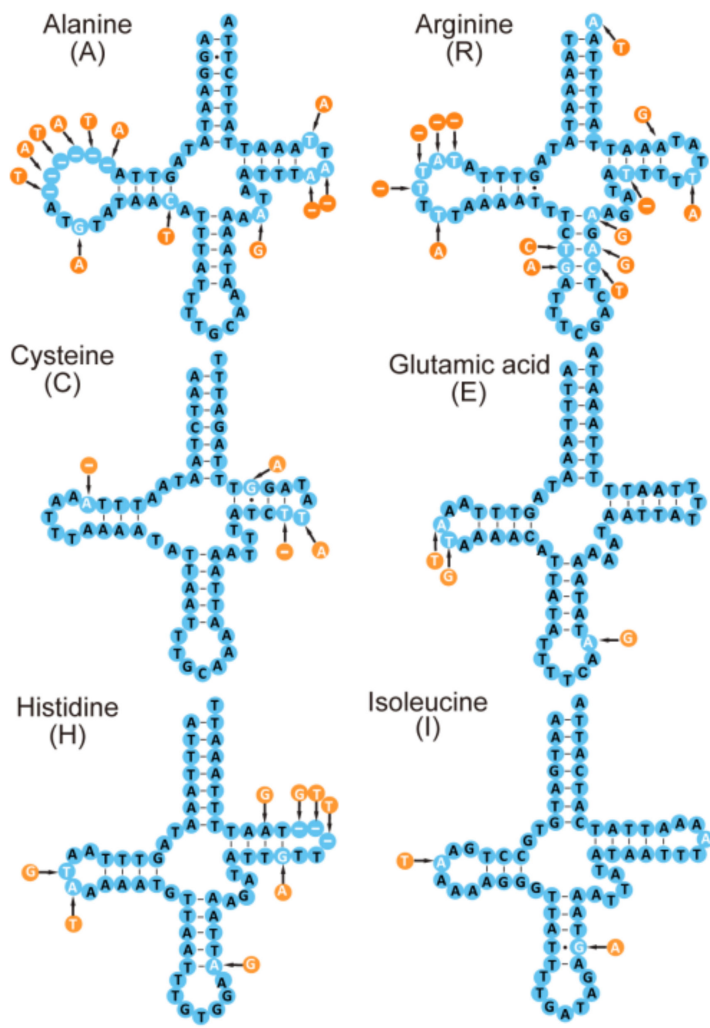

Glutamic acid $A-A$
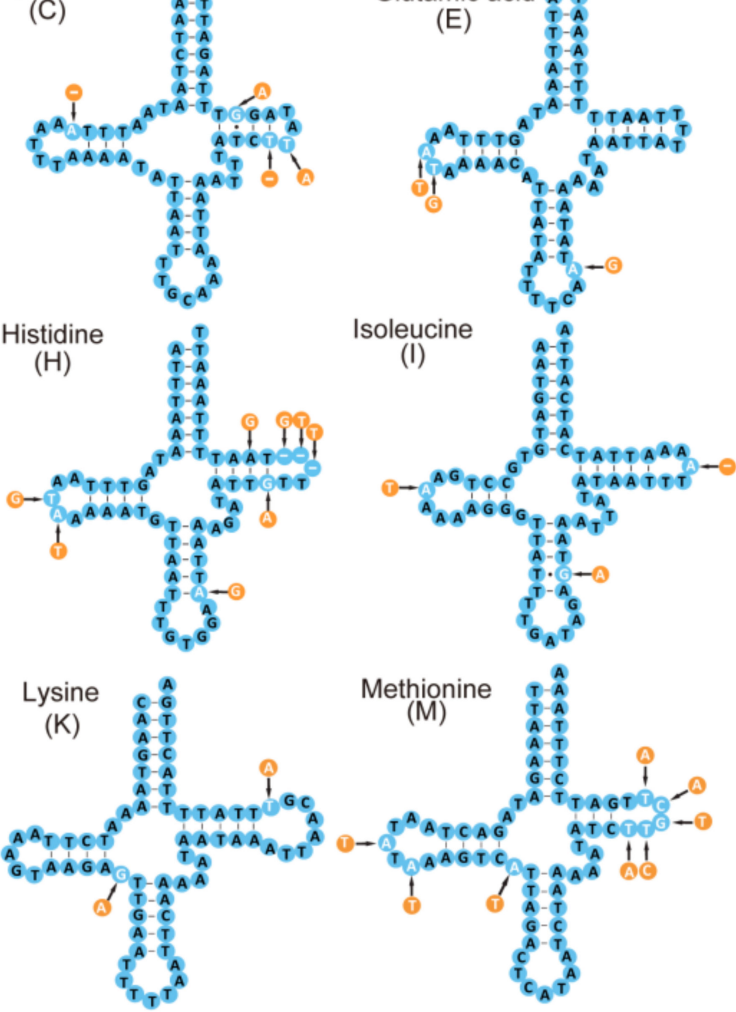

Methionine

(M
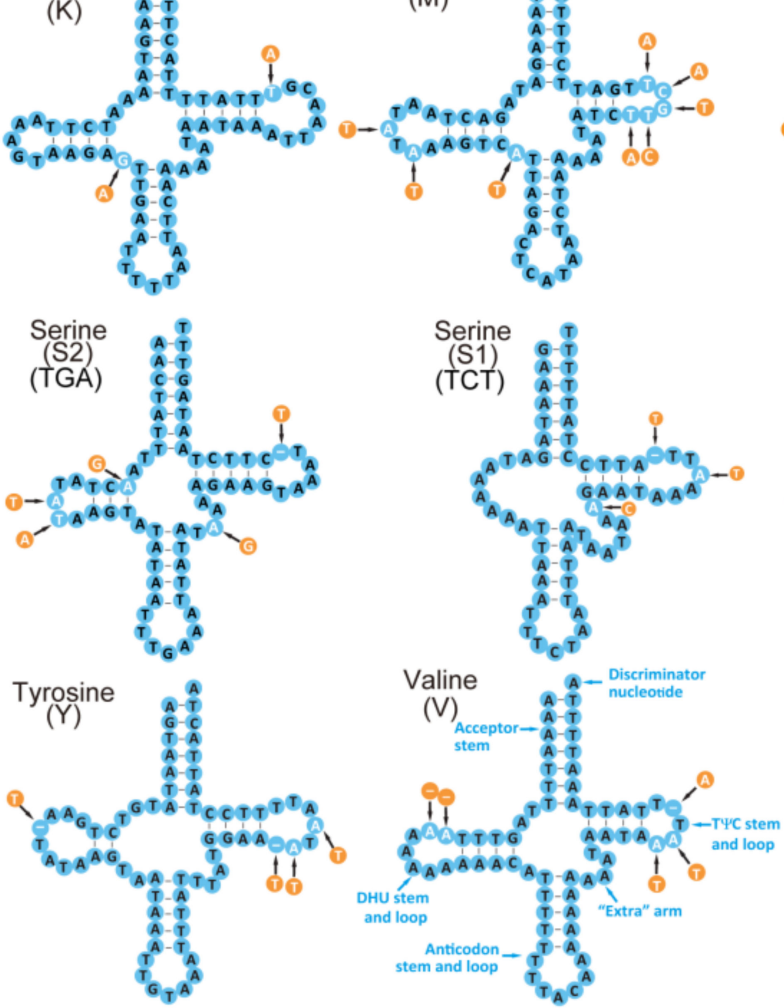
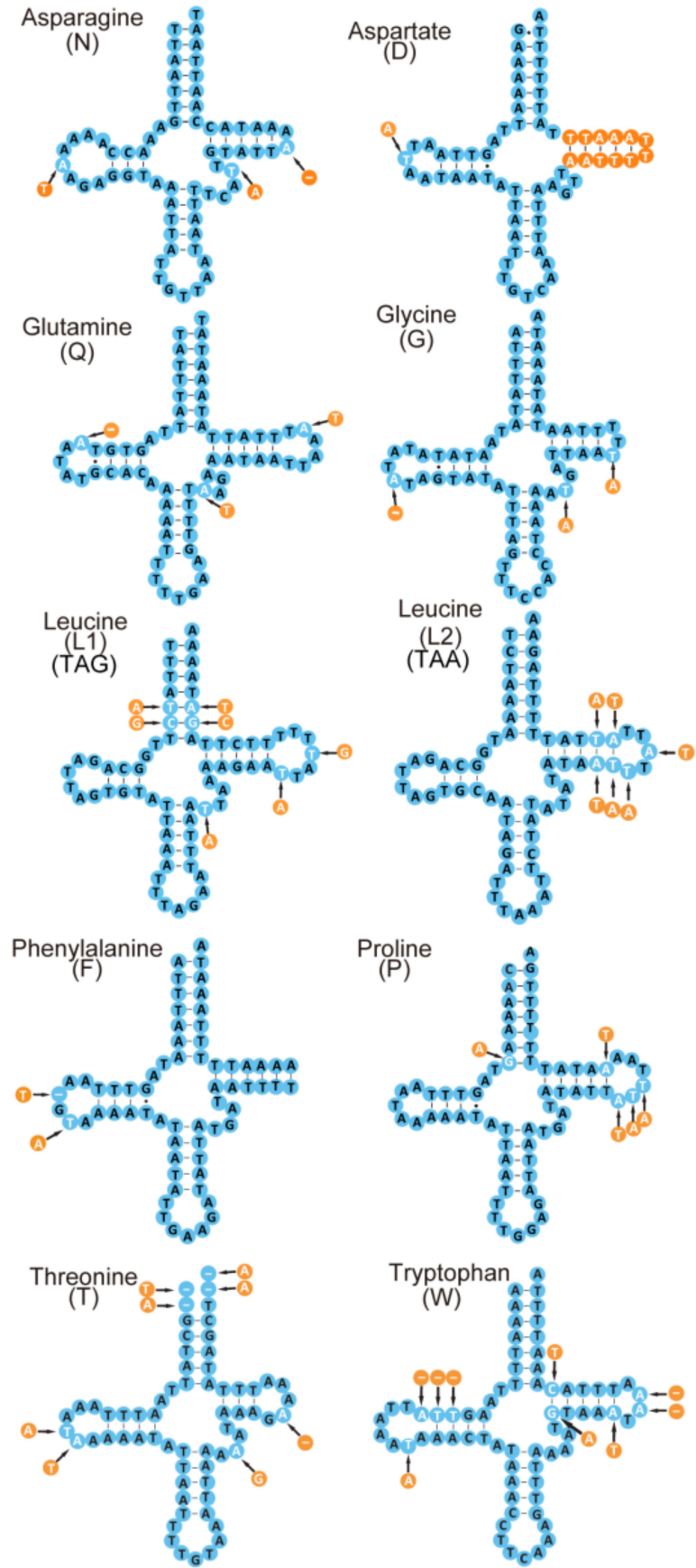

N Identical in two species

(1) Brachymeria lasus

(1) Haltichella nipponensis

Figure 3. Predicted secondary structure for the tRNAs of B. lasus and H. nipponensis. The tRNAs are labeled with the abbreviations of their corresponding amino acids. Dashes indicate the Watson-Crick base pairs, and dots indicate the wobble GT pairs. 


\subsection{A+T-Rich Region}

In the mitogenome, the largest non-coding region is normally the $\mathrm{A}+\mathrm{T}$-rich region (also called the control region). The $\mathrm{A}+\mathrm{T}$-rich regions of Chalcididae mitogenomes are located between the rrnS and trnM genes, and the length was $236 \mathrm{bp}$ for B. lasus and $289 \mathrm{bp}$ for H. nipponensis. The A+T\% content was $94.9 \%$ and $90.3 \%$ in the mitochondrial genomes of $B$. lasus and $H$. nipponensis, respectively. Though the alignment indicates that $B$. lasus and $H$. nipponensis share a similar control region, only in H. nipponensis were two repeat units of $135 \mathrm{bp}$ found.

\subsection{Phylogenetic Analysis}

Phylogenetic analyses of two concatenated datasets (PCG123 and PCG12) were conducted using BI and ML, and are shown in Figure 4 (Supplementary Figures S2-S4). All the resulting trees supported the monophyly of Chalcididae, consistent with the previous comments derived from combined morphological and molecular characters [9], although this study only included two of five recognized subfamilies of Chalcididae. However, the result of ribosomal genes (18S and 28S) in Munro et al. [6] suggested that five subfamilies were scattered across the phylogenetic tree of superfamily Chalcidoidea. Brachymeria and Haltichella belong to the subfamilies Chalcidinae and Haltichellinae of Chalcididae, respectively. In our results, the phylogenetic relationship of B. latus was closer to Haltichella, with higher support values than B. sp. [18] (Supplementary Figures S2-S4). This result indicates that Brachymeria is paraphyletic, and needs validation by further studies. These issues alerted us the necessity of continuously sampling mitogenomes of other subfamilies in the future.

For the phylogenetic relationships in Chalcidoidea, all the resulting trees supported a hypothesis with a grouping of Mymaridae + (Chalcididae + remaining Chalcidoidea in our dataset), while the topologies between BI and ML trees showed apparent inconsistencies in the remaining Chalcidoidea. The basal position of Mymaridae was concordant with the published molecular results $[5-9,55,56]$. Chalcididae has been supported as the sister lineage with the remaining taxa of Chalcidoidea, excluding Mymaridae.

For the remaining Chalcidoidea, both the BI and ML results of the PCG123 dataset supported Agaonidae as the sister group of the other families with the medium support value $(B S=79 ; \mathrm{PP}=0.95)$. PCG123 trees also showed a similar topology to other families, except for Pteromalidae and Encyrtidae, and ML analysis supported Pteromalidae $(\mathrm{BS}=74)$ as the sister group of these follow-up families, while BI supported Encyrtidae $(\mathrm{PP}=1)$. Excluding Mymaridae and Chalcididae, the PCG12 dataset supported Trichogrammatidae as the sister group to other families with a high nodal value $(\mathrm{BS}=71 ; \mathrm{PP}=0.99)$. Aphelinidae, as the next successive group, only received a high support value in BI analysis $(\mathrm{PP}=0.99)$ (Figure 4; Supplementary Figures S2-S4).

All the trees seemed to share one important similarity with earlier molecular phylogenetic efforts: strong support for the monophyly of many families, but a largely unresolved or unstable "backbone" of relationships among families $[5-9,55,56]$. The Chalcidoidea are one of the most megadiverse groups of insects [2], whose family numbers appear to have undergone extremely rapid radiation in the post-Cretaceous era according to the fossil records and molecular dating hypothesis [7]. Therefore, resolving the phylogenetic relationships within radiated Chalcidoidea seems to be an extremely hard task. 

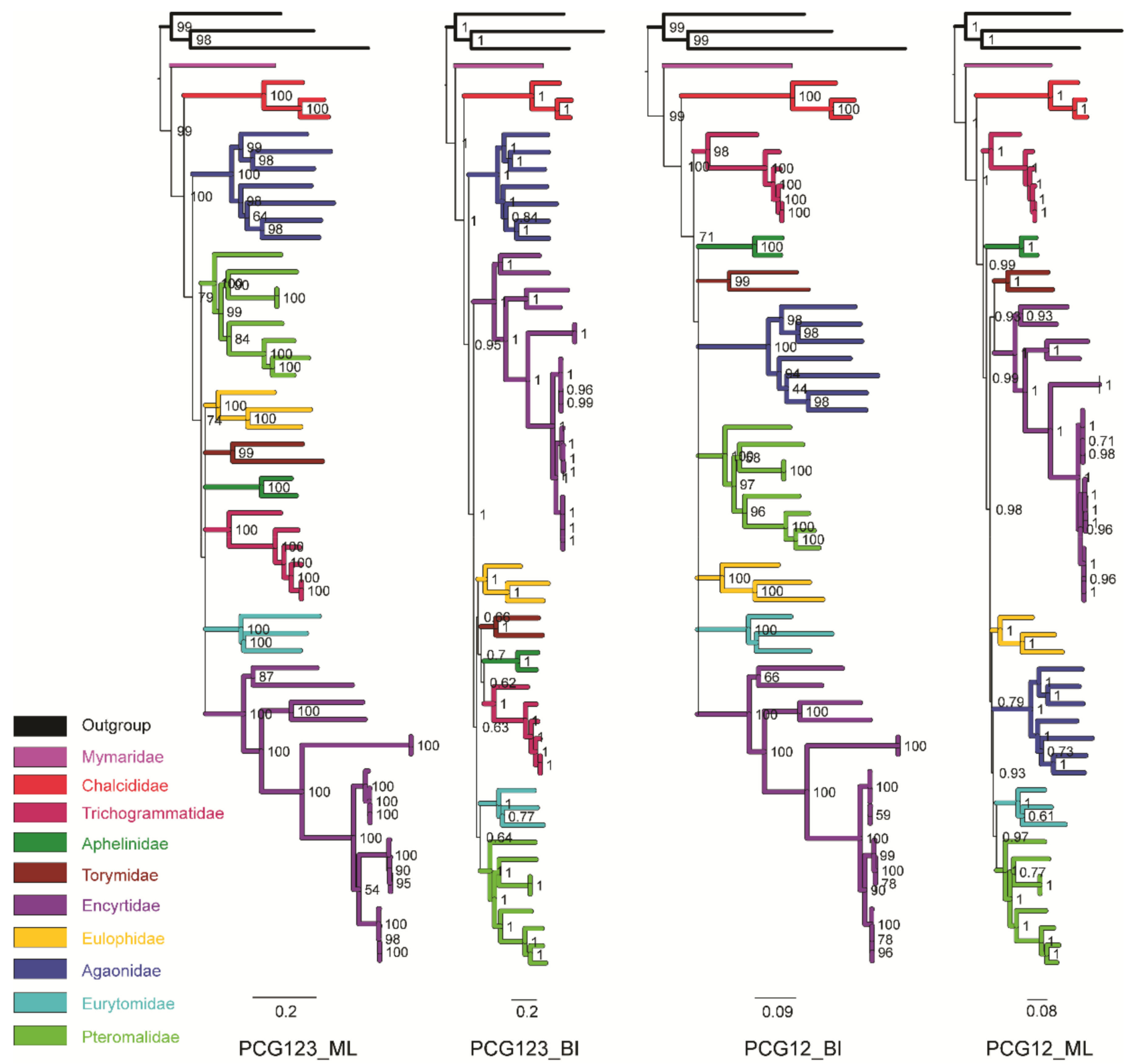

Figure 4. Phylogenetic trees constructed by ML/BI methods based on the dataset of PCG123 and PCG12. In the ML tree, all nodes of bootstrap value lower than 50 were shown as polytomy.

\section{Conclusions}

In this study, two newly complete mitogenomes (B. lasus and H. nipponensis) have been sequenced and exhibited quite similar features in the genome size, base content, AT nucleotide bias, AT skew, GC skew, codon usage of protein genes, and secondary structure of tRNAs.

Phylogenetic analysis based on two datasets (PCG123 and PCG12) with two methods (maximum likelihood and Bayesian inference) indicated the monophyly of Chalcididae, although the sampling needs to be increased, and Brachymeria, as the largest genus in Chalcididae, might be not monophyletic. Our trees supported the basal position of Mymaridae, and recovered Mymaridae as the sister group of the remaining Chalcidoidea, as well as Chalcididae is the sister to the remaining chalcidoids, except for Mymaridae, in our mitogenomic phylogenetic analysis. 
More mitogenomic data for Chalcididae and Chalcidoidea should be added to verify the monophyly of Chalcididae and elucidate the relationships between Chalcididae and other families in this mega-radiated superfamily in the future.

Supplementary Materials: The following are available online at https:/ / www.mdpi.com/article/10 .3390 /insects12121049/s1, Table S1: The best fit DNA model of each locus in datasets PCG123 and PCG12 selected by jModeltest 2.1.7, Table S2: Nucleotide composition of mitochondrial genomes of two Chalcididae species, Figure S1: The mitogenome map of Brachymeria sp., Figure S2: Phylogenetic relationships among Chalcidoidea species by BI analysis based on the PCG123 dataset, Figure S3: Phylogenetic relationships among Chalcidoidea species by ML analysis based on the PCG123 dataset, Figure S4: Phylogenetic relationships among Chalcidoidea species by BI analysis based on the PCG12 dataset, Figure S5: Phylogenetic relationships among Chalcidoidea species by ML analysis based on the PCG12 dataset.

Author Contributions: Conceptualization, Y.Q. and H.Z.; specimen identification, Z.W. and Y.C.; methodology and experiments, Y.Q. and H.Z.; data analysis, H.Z. and Y.Q.; writing-original draft preparation, Y.Q. and H.Z.; writing-review and editing, Y.Q., H.Z., Y.C., H.C. and Z.W.; funding acquisition, H.C., H.Z. and Y.Q. All authors have read and agreed to the published version of the manuscript.

Funding: This research was funded by the National Natural Science Foundation of China (No. 31970396) to H.C. and by the Science and Technology Project of Hebei Education Department (QN2021126) to H.Z. and the Ph.D. Research Startup Foundation of Langfang Normal University (XBQ202143) to Y.Q.

Institutional Review Board Statement: Not applicable.

Data Availability Statement: Both sequences of mitogenomes were deposited in the GenBank under accession numbers of MZ615567 and MZ615568.

Acknowledgments: We express our thanks to the four anonymous reviewers for their professional suggestions that improved the quality of this research, and to Shuqiang Li (Key Laboratory of Zoological Systematics and Evolution, Chinese Academy of Sciences, China) for providing support during collecting trips in Xishuangbanna.

Conflicts of Interest: The authors declare no conflict of interest.

\section{References}

1. Nedoluzhko, A.V.; Sharko, F.S.; Boulygina, E.S.; Tsygankova, S.V.; Sokolov, A.S.; Mazur, A.M.; Polilov, A.A.; Prokhortchouk, E.B.; Skryabin, K.G. Mitochondrial genome of Megaphragma amalphitanum (Hymenoptera: Trichogrammatidae). Mitochondrial DNA Part A DNA Mapp. Seq. Anal. 2016, 27, 4526-4527. [CrossRef]

2. Noyes, J.S. Universal Chalcidoidea Database. 2021. Available online: www.nhm.ac.uk/jdsml/researchcuration/projects/ chalcidoids (accessed on 18 August 2021).

3. Wijesekara, G.A.W. Phylogeny of Chalcididae (Insecta: Hymenoptera) and its congruence with contemporary heirarchical classification. Contrib. Am. Entomol. Inst. 1997, 29, 1-61.

4. Gibson, G.A.P. Sister-group relationships of the Platygastroidea and Chalcidoidea (Hymenoptera)-An alternate hypothesis to Rasnitsyn (1988). Zool. Scr. 1999, 28, 125-138. [CrossRef]

5. Campbell, B.; Heraty, J.M.; Rasplus, J.-Y.; Chan, K.; Steffen-Campbell, J.; Babcock, C. Molecular Systematics of the Chalcidoidea Using 28S-D2 rDNA; CSIRO Publishing: Collingwood, Australia, 2000; pp. 57-71.

6. Munro, J.; Heraty, J.; Burks, R.; Hawks, D.; Mottern, J.; Cruaud, A.; Rasplus, J.-Y.; Jansta, P. A Molecular Phylogeny of the Chalcidoidea (Hymenoptera). PLoS ONE 2011, 6, e27023. [CrossRef]

7. $\quad$ Peters, R.S.; Niehuis, O.; Gunkel, S.; Bläser, M.; Mayer, C.; Podsiadlowski, L.; Kozlov, A.; Donath, A.; van Noort, S.; Liu, S.; et al. Transcriptome sequence-based phylogeny of chalcidoid wasps (Hymenoptera: Chalcidoidea) reveals a history of rapid radiations, convergence, and evolutionary success. Mol. Phylogenet. Evol. 2018, 120, 286-296. [CrossRef]

8. Zhang, J.; Lindsey, A.R.I.; Peters, .S.; Heraty, J.M.; Hopper, K.R.; Werren, J.H.; Martinson, E.O.; Woolley, J.B.; Yoder, M.J.; Krogmann, L. Conflicting signal in transcriptomic markers leads to a poorly resolved backbone phylogeny of chalcidoid wasps. Syst. Entomol. 2020, 45, 783-802. [CrossRef]

9. Heraty, J.M.; Burks, R.A.; Cruaud, A.; Gibson, G.A.P.; Liljeblad, J.; Munro, J.; Rasplus, J.-Y.; Delvare, G.; Janšta, P.; Gumovsky, A.; et al. A phylogenetic analysis of the megadiverse Chalcidoidea (Hymenoptera). Cladistics 2013, 29, 466-542. [CrossRef]

10. Boore, J.L. Animal mitochondrial genomes. Nucleic Acids Res. 1999, 27, 1767-1780. [CrossRef] [PubMed] 
11. Gazi, M.; Sultana, T.; Min, G.-S.; Park, Y.C.; García-Varela, M.; Nadler, S.A.; Park, J.-K. The complete mitochondrial genome sequence of Oncicola luehei (Acanthocephala: Archiacanthocephala) and its phylogenetic position within Syndermata. Parasitol. Int. 2012, 61, 307-316. [CrossRef] [PubMed]

12. Gazi, M.; Kim, J.; Park, J.-K. The complete mitochondrial genome sequence of Southwellina hispida supports monophyly of Palaeacanthocephala (Acanthocephala: Polymorphida). Parasitol. Int. 2015, 64, 64-68. [CrossRef] [PubMed]

13. Gazi, M.; Kim, J.; García-Varela, M.; Park, C.; Littlewood, D.T.J.; Park, J.-K. Mitogenomic phylogeny of Acanthocephala reveals novel Class relationships. Zool. Scr. 2016, 45, 437-454. [CrossRef]

14. Sun, S.E.; Sha, Z.; Wang, Y. Mitochondrial phylogenomics reveal the origin and adaptive evolution of the deep-sea caridean shrimps (Decapoda: Caridea). J. Oceanol. Limnol. 2021, 39, 1948-1960. [CrossRef]

15. Cheng, J.; Chan, T.-Y.; Zhang, N.; Sun, S.; Sha, Z. Mitochondrial phylogenomics reveals insights into taxonomy and evolution of Penaeoidea (Crustacea: Decapoda). Zool. Scr. 2018, 47, 582-594. [CrossRef]

16. Bourguignon, T.; Tang, Q.; Ho, S.Y.W.; Juna, F.; Wang, Z.; Arab, D.A.; Cameron, S.L.; Walker, J.; Rentz, D.; Evans, T.A.; et al. Transoceanic Dispersal and Plate Tectonics Shaped Global Cockroach Distributions: Evidence from Mitochondrial Phylogenomics. Mol. Biol. Evol. 2018, 35, 970-983. [CrossRef] [PubMed]

17. Li, H.; Leavengood, J.M., Jr.; Chapman, E.G.; Burkhardt, D.; Song, F.; Jiang, P.; Liu, J.; Zhou, X.; Cai, W. Mitochondrial phylogenomics of Hemiptera reveals adaptive innovations driving the diversification of true bugs. Proc. R. Soc. B Biol. Sci. 2017, 284, 20171223. [CrossRef]

18. Tang, P.; Zhu, J.; Zheng, B.; Wei, S.; Sharkey, M.; Chen, X.; Vogler, A.P. Mitochondrial phylogenomics of the Hymenoptera. Mol. Phylogenet. Evol. 2019, 131, 8-18. [CrossRef]

19. Abascal, F.; Posada, D.; Knight, R.D.; Zardoya, R. Parallel evolution of the genetic code in arthropod mitochondrial genomes. PLoS Biol. 2006, 4, e127. [CrossRef]

20. Cameron, S.L. Insect Mitochondrial Genomics: Implications for Evolution and Phylogeny. Annu. Rev. Entomol. 2014, 59, 95-117. [CrossRef] [PubMed]

21. Wilson, A.C.; Cann, R.L.; Carr, S.M.; George, M.; Gyllensten, U.B.; Helm-Bychowski, K.M.; Higuchi, R.G.; Palumbi, S.R.; Prager, E.M.; Sage, R.D.; et al. Mitochondrial DNA and two perspectives on evolutionary genetics. Biol. J. Linn. Soc. 1985, 26, 375-400. [CrossRef]

22. Ilyasov, R.; Park, J.; Takahashi, J.; Kwon, H.-W. Phylogenetic Uniqueness of Honeybee Apis Cerana from the Korean Peninsula Inferred from The Mitochondrial, Nuclear, and Morphological Data. J. Apic. Sci. 2018, 62, 189-214. [CrossRef]

23. Ilyasov, R.A.; Youn, H.G.; Lee, M.-L.; Kim, K.W.; Proshchalykin, M.Y.; Lelej, A.S.; Takahashi, J.-I.; Kwon, H.W. Phylogenetic Relationships of Russian Far-East with Other North Asian Populations. J. Apic. Sci. 2019, 63, 289-314. [CrossRef]

24. Gibson, G.A.P. Chalcididae. In Annotated Keys to the Genera of Nearctic Chalcidoidea (Hymenoptera); Gibson, G.A.P., Huber, J.T., Woolley, J.B., Eds.; NRC Research Press: Ottawa, ON, Canada, 1997.

25. Narendran, T.C.; van Achterberg, C. Revision of the family Chalcididae (Hymenoptera, Chalcidoidea) from Vietnam, with the description of 13 new species. ZooKeys 2016, 576, 1-202.

26. Meng, G.; Li, Y.; Yang, C.; Liu, S. MitoZ: A toolkit for animal mitochondrial genome assembly, annotation and visualization. Nucleic Acids Res. 2019, 47, e63. [CrossRef] [PubMed]

27. Tamura, K.; Peterson, D.; Peterson, N.; Stecher, G.; Nei, M.; Kumar, S. MEGA5: Molecular evolutionary genetics analysis using maximum likelihood, evolutionary distance, and maximum parsimony methods. Mol. Biol. Evol. 2011, 28, 2731-2739. [CrossRef] [PubMed]

28. Perna, N.T.; Kocher, T.D. Patterns of nucleotide composition at fourfold degenerate sites of animal mitochondrial genomes. J. Mol. Evol. 1995, 41, 353-358. [CrossRef] [PubMed]

29. Xiao, J.; Wang, N.; Murphy, R.W.; Cook, J.; Jia, L.; Huang, D. Wolbachia Infection And Dramatic Intraspecific Mitochondrial DNA Divergence in a Fig Wasp. Evolution 2012, 66, 1907-1916. [CrossRef]

30. Wang, J.; Liu, J.; Miao, Y.; Huang, D.; Xiao, J. Tracking the Distribution and Burst of Nuclear Mitochondrial DNA Sequences (NUMTs) in Fig Wasp Genomes. Insects 2020, 11, 680. [CrossRef]

31. Du, Y.; Song, X.; Liu, X.; Ouyang, Z.; Lu, Z. Mitochondrial genome of Tamarixia radiata (Hymenoptera: Chalcidoidea: Eulophidae) and phylogenetic analysis. Mitochondrial DNA Part B 2019, 4, 2839-2840. [CrossRef] [PubMed]

32. Zhu, J.; Tang, P.; Zheng, B.; Wu, Q.; Wei, S.; Chen, X. The first two mitochondrial genomes of the family Aphelinidae with novel gene orders and phylogenetic implications. Int. J. Biol. Macromol. 2018, 118, 386-396. [CrossRef]

33. Xiong, M.; Zhou, Q.-S.; Zhang, Y.-Z. The complete mitochondrial genome of Encyrtus infelix (Hymenoptera: Encyrtidae). Mitochondrial DNA Part B 2019, 4, 114-115. [CrossRef]

34. Ma, Y.; Zheng, B.; Zhu, J.; Tang, P.; Chen, X. The mitochondrial genome of Aenasius arizonensis (Hymenoptera: Encyrtidae) with novel gene order. Mitochondrial DNA Part B 2019, 4, 2023-2024. [CrossRef]

35. Du, Y.; Song, X.; Liu, X.; Zhong, B. Mitochondrial genome of Diaphorencyrtus aligarhensis (Hymenoptera: Chalcidoidea: Encyrtidae) and phylogenetic analysis. Mitochondrial DNA Part B 2019, 4, 3190-3191. [CrossRef]

36. Tian, X.; Xian, X.; Zhang, G.; Castañé, C.; Romeis, J.; Wan, F.; Zhang, Y. Complete mitochondrial genome of a predominant parasitoid, Necremnus tutae (Hymenoptera: Eulophidae) of the South American tomato leafminer Tuta absoluta (Lepidoptera: Gelechiidae). Mitochondrial DNA Part B 2021, 6, 562-563. [CrossRef] [PubMed] 
37. Tang, X.; Lyu, B.; Lu, H.; Tang, J.; Meng, R.; Cai, B. The mitochondrial genome of a parasitic wasp, Chouioia cunea Yang (Hymenoptera: Chalcidoidea: Eulophidae) and phylogenetic analysis. Mitochondrial DNA Part B 2021, 6, 872-874. [CrossRef] [PubMed]

38. Su, T.; Huang, D.; Wu, Y.; He, B.; Liang, A. Sequencing and characterization of mitochondrial genome of Eurytoma sp. (Hymenoptera: Eurytomidae). Mitochondrial DNA Part B 2016, 1, 826-828. [CrossRef]

39. Shen, Z.; Chen, L.; Chen, L.; Li, Y. Information from the mitochondrial genomes of two egg parasitoids, Gonatocerus sp. and Telenomus sp., reveals a controversial phylogenetic relationship between Mymaridae and Scelionidae. Genomics 2019, 111, 1059-1065. [CrossRef] [PubMed]

40. Xiao, J.; Jia, J.; Murphy, R.W.; Huang, D. Rapid Evolution of the Mitochondrial Genome in Chalcidoid Wasps (Hymenoptera: Chalcidoidea) Driven by Parasitic Lifestyles. PLoS ONE 2011, 6, e26645. [CrossRef]

41. Yan, Z.; Fang, Q.; Tian, Y.; Wang, F.; Chen, X.; Werren, J.H.; Ye, G. Mitochondrial DNA and their nuclear copies in the parasitic wasp Pteromalus puparum: A comparative analysis in Chalcidoidea. Int. J. Biol. Macromol. 2019, 121, 572-579. [CrossRef] [PubMed]

42. Wu, Y.; Yang, H.; Feng, Z.; Li, B.; Zhou, W.; Song, F.; Li, H.; Zhang, L.; Cai, W. Novel gene rearrangement in the mitochondrial genome of Pachyneuron aphidis (Hymenoptera: Pteromalidae). Int. J. Biol. Macromol. 2020, 149, 1207-1212. [CrossRef]

43. Huang, Z.; Dai, H.; Lin, Q.; Zhang, B. The mitochondrial genome of parasitic wasp: Anisopteromalus calandrae (Howard, 1881) (Hymenoptera: Pteromalidae). Mitochondrial DNA Part B 2021, 6, 2048-2049. [CrossRef] [PubMed]

44. Yang, J.; Liu, H.; Li, Y.; Wei, Z. The rearranged mitochondrial genome of Podagrion sp. (Hymenoptera: Torymidae), a parasitoid wasp of mantis. Genomics 2019, 111, 436-440. [CrossRef] [PubMed]

45. Chen, L.; Chen, P.; Xue, X.; Hua, H.; Li, Y.; Zhang, F.; Wei, S. Extensive gene rearrangements in the mitochondrial genomes of two egg parasitoids, Trichogramma japonicum and Trichogramma ostriniae (Hymenoptera: Chalcidoidea: Trichogrammatidae). Sci. Rep. 2018, 8, 7034. [CrossRef] [PubMed]

46. Xue, S.; Zhang, Y.; Gao, S.; Lu, S.; Wang, J.; Zhang, K. Mitochondrial genome of Trichagalma acutissimae (Hymenoptera: Cynipoidea: Cynipidae) and phylogenetic analysis. Mitochondrial DNA Part B 2020, 5, 1073-1074. [CrossRef]

47. Li, X.; Li, Z.; Zhu, J.; Zheng, B.; Tang, P.; Chen, X. The mitochondrial genome of Telenomus remus (Hymenoptera: Platygastridae). Mitochondrial DNA Part B 2021, 6, 844-845. [CrossRef] [PubMed]

48. Xian, Z.; Pan, Z.; Chen, J.; Zhu, J.; Zhou, S.; Pang, L.; Shi, M.; Chen, X.; Huang, J. The complete mitochondrial genome of Trichopria drosophilae (Hymenoptera: Diapriidae). Mitochondrial DNA Part B 2020, 5, 2391-2393. [CrossRef] [PubMed]

49. Rambaut, A.; Suchard, M.A.; Xie, D.; Drummond, A. Tracer v1.6. Available online: http://tree.bio.ed.ac.uk/software/tracer (accessed on 6 September 2020).

50. Darriba, D.; Taboada, G.L.; Doallo, R.; Posada, D. jModelTest 2: More models, new heuristics and parallel computing. Nat. Methods 2012, 9, 772. [CrossRef] [PubMed]

51. Stamatakis, A. RAxML version 8: A tool for phylogenetic analysis and post-analysis of large phylogenies. Bioinformatics 2014, 30, 1312-1313. [CrossRef] [PubMed]

52. Rambaut, A. Figtree 1.4.0. Available online: http://tree.bio.ed.ac.uk/software/figtree (accessed on 18 August 2020).

53. Ojala, D.; Montoya, J.; Attardi, G. tRNA punctuation model of RNA processing in human mitochondria. Nature 1981, 290, 470-474. [CrossRef]

54. Lavrov, D.V.; Boore, J.L.; Brown, W.M. The Complete Mitochondrial DNA Sequence of the Horseshoe Crab Limulus polyphemus. Mol. Biol. Evol. 2000, 17, 813-824. [CrossRef] [PubMed]

55. Heraty, J.; Ronquist, F.; Carpenter, J.M.; Hawks, D.; Schulmeister, S.; Dowling, A.P.; Murray, D.; Munro, J.; Wheeler, W.C.; Schiff, N. Evolution of the hymenopteran megaradiation. Mol. Phylogenet. Evol. 2011, 60, 73-88. [CrossRef]

56. Sharkey, M.J.; Carpenter, J.M.; Vilhelmsen, L.; Heraty, J.; Liljeblad, J.; Dowling, A.P.G.; Schulmeister, S.; Murray, D.; Deans, A.R.; Ronquist, F.; et al. Phylogenetic relationships among superfamilies of Hymenoptera. Cladistics 2011, 28, 80-112. [CrossRef] 